\title{
Classification of gastric cancer patients based on HLA antigen expression using quantification method III
}

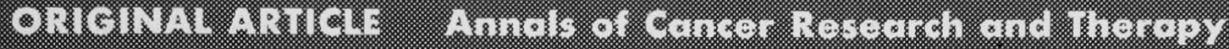

\author{
Fumi Hayashi ${ }^{* 1}$, Chikio Hayashi ${ }^{* 2)}$, Kyoji Ogoshi ${ }^{* 3)}$
}

\begin{abstract}
We have previously presented results suggesting that HLA antigen status could predict the response of cancer to therapy, and have proposed that rational individualized therapy for cancer patients might possibly be designed by evaluating HLA antigens. In this study, we classified gastric cancer patients into four groups using quantification method III and then developed a simple method of classifying patients to HLA antigen status for easy clinical application.

Ann Cancer Res Ther 3(2):117 120, 1994/Received 24 Sept 1994, Accepted 24 Oct 1994

Key words : HLA antigen, gastric cancer, quantification method III
\end{abstract}

Development of parameters that correlate with the response of cancer patients to treatment would allow the more rational and suitable use of anticancer therapy. The human major histocompatibility complex(MHC), also referred to as the human leucocyte antigen(HLA) complex, is located on a small part of chromosome 6 , and is by far the most variable part of the genome and initiates immune responses. We have previously presented results suggesting that HLA status could predict the response to anticancer therapy, and have proposed that rational individualized therapy for cancer patients might possibly be designed by evaluating HLA antigens").

The survival of gastric cancer patients in Japan appears to be better than in the West ${ }^{2)}$, suggesting that patients may respond differently to anticancer therapy in Japan or that there are different patterns of gastric cancer in Japan and Western countries ${ }^{3 \text {. }}$.

We know that the HLA antigen status of the Japanese is different from that of Caucasians. Thus, a different response to anticancer therapy combined with different therapeutic strategies may produce distinct outcomes.

In this study, we classified gastric cancer patients using quantification method III, which is one method of multidimensional data analysis ${ }^{4,5}$ and is equivalent to the correspondence analysis method by Benzécri ${ }^{6,7)}$. We then developed a simple method of classifying patients according to HLA antigen status for easy clinical application.

\footnotetext{
"'School of Humanity, Tokyo Eiwa Women's University, *2)Institute of Statistical Mathematics,

-3)Second Department of Surgery, School of Medicine, Tokai University Correspondence to: Fumi Hayashi, School of Humanity. Tokyo Eiwa Women's University, 32- 1, Miho-cho, Midori-ku, Yokohama-shi, 226 Japan
}

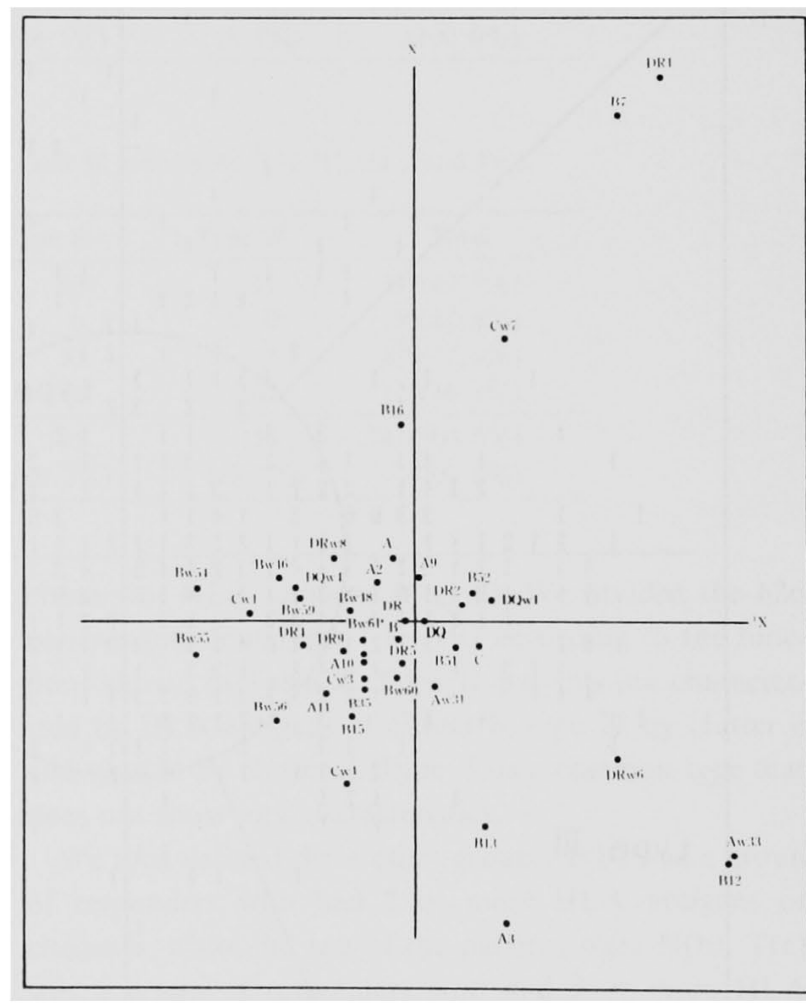

Fig. 1 Scattergram of the HLA antigens in 626 patients (quantification method III)

\section{Materials and methods}

We first analyzed the data of 626 gastric cancer patients and then assessed 741 patients. We examined HLA A, B, C, DR and DQ loci using the assay. HLA antigens with a frequency $>1 \%$ and blank antigens were assessed as follows: A loci-2, 3, 9, 10, 11, 31, 33: B loci-7, 12, 13, 15, 16, 35, 46, 48, 51, 52, 54, 55, 56, 59, 60,61: C loci - wl, w3, w4, w7 : DR loci - 1, 2, 4, 5, 6, 
Table 1 The main HLA antigens in each cluster

\begin{tabular}{l|l}
\hline b & A3, A33, B12, B13, DR6 \\
\hline & $\begin{array}{l}\text { Bw46, Bw54, Bw55, Bw56, Bw59, Cw1, DR4, } \\
\text { D } \\
\text { (B22 was subdivided to Bw54, Bw55, Bw56) }\end{array}$ \\
\hline d & B 7, B15, Cw7, DR1 \\
\hline
\end{tabular}

Table 2 The functions dividing patients scattered on 2 -dimensional space ${ }^{1} \mathrm{Y}$ and ${ }^{2} \mathrm{Y}$

Type I : ${ }^{1} \mathrm{Y}^{2}+{ }^{2} \mathrm{Y}^{2}<0.7$

Type II : ${ }^{2} \mathrm{Y}<{ }^{1} Y / 3$ and ${ }^{2} Y \leq 3 *^{1} Y$, except type I

Type III : ${ }^{2} Y<-2 *{ }^{1} Y$ and ${ }^{2} Y>3 *{ }^{1} Y$, except type I

Type $\mathrm{N}:{ }^{2} \mathrm{Y}>{ }^{2} \mathrm{Y} / 3$ and ${ }^{2} \mathrm{Y} \leq-2 *{ }^{1} \mathrm{Y}$, except type I

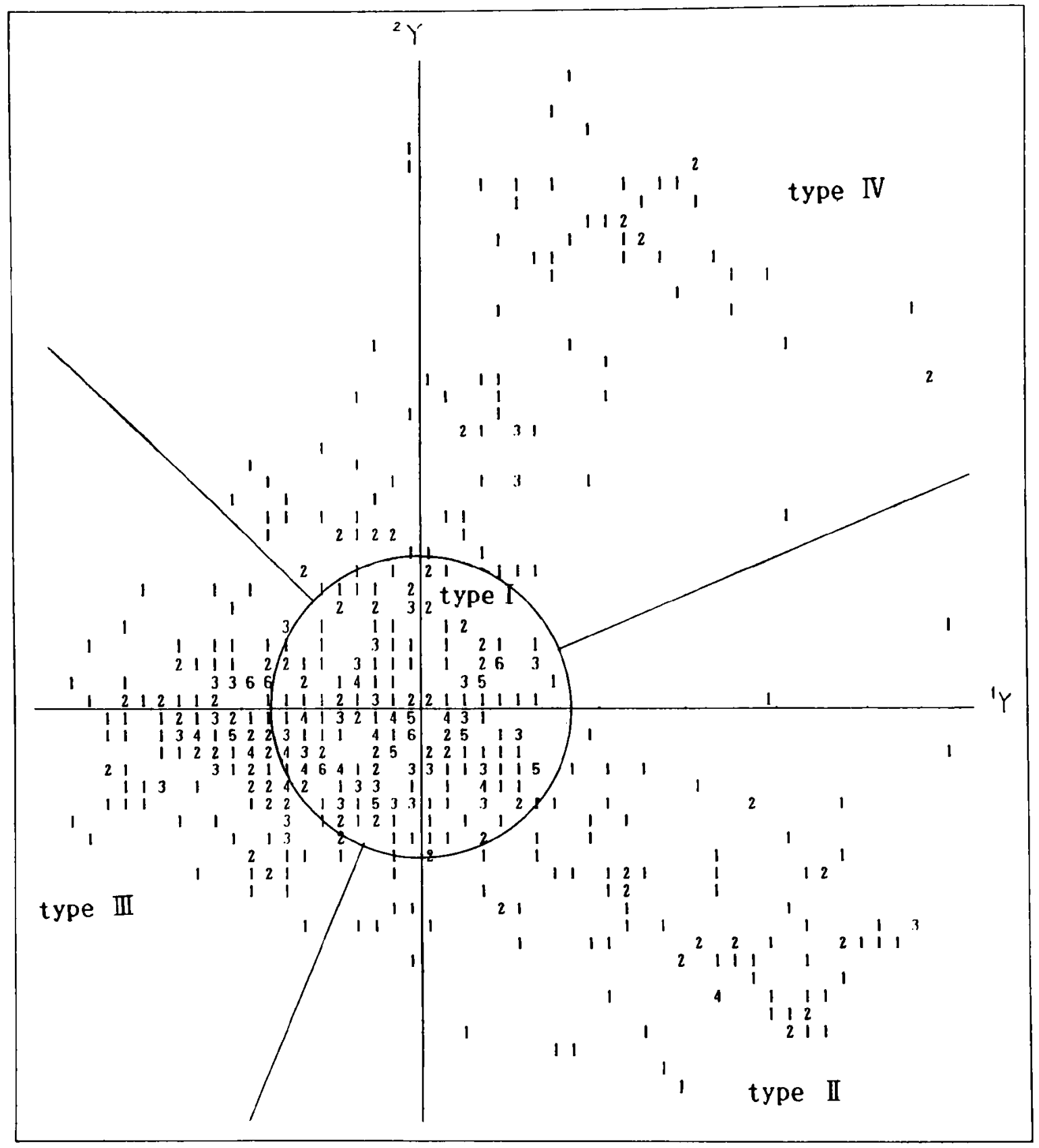

Fig. 2 Scattergram of the individual patients

8, 9 : DQ loci - 1, 3, 4 : and A blank, B blank, Cw blank, DR blank, and DQ blank.

Figure 1 shows a scattergram of the HLA antigen status of 626 patients. Cluster $a$ is located in the center, and the remaining $b, c$, and $d$ clusters located in each direction $(1 \mathrm{X} * 2 \mathrm{X})$. Table 1 shows the HLA antigens in each cluster. Individual patients are scattered in twodimensional regions that $(1 Y * 2 Y)$ correspond to the 
Table 3 The relationship of types I, II, III, and IV to type (T(b), T(c), and T(d))

\begin{tabular}{lrrrrr}
\hline & Type I & Type II & Type III & Type IV & Total \\
\hline$T(b) \& N(c) \& N(d)$ & 0 & 77 & 0 & 0 & 77 \\
$T($ b) \& $T($ c) \& N(d) & 1 & 4 & 0 & 0 & 5 \\
$T($ b) \& N(c) \& T(d) & 0 & 3 & 0 & 4 & 7 \\
$N($ b) \& T(c) \& N(d) & 11 & 0 & 88 & 0 & 99 \\
$N(b) \& T(c) \& T(d)$ & 1 & 0 & 6 & 2 & 9 \\
$N(b) \& N(c) \& T(d)$ & 15 & 0 & 1 & 74 & 90 \\
$N(b) \& N(c) \& N(d)$ & 244 & 18 & 71 & 6 & 339 \\
\hline Total & 272 & 102 & 166 & 86 & 626 \\
\hline
\end{tabular}

note : There were no patients with type $T(\mathrm{~b}) \& \mathrm{~T}(\mathrm{c}) \& \mathrm{~T}(\mathrm{~d})$

Table 4 Cross-tabulation of types I, II, III, and IV with types I', II', III', and IV'

\begin{tabular}{crrrrr}
\hline & Type I & Type II & Type III & Type IV & Total \\
\hline Type I' & 244 & 18 & 71 & 6 & $339(54.2 \%)$ \\
Type II & 1 & 81 & 0 & 0 & $82(13.1 \%)$ \\
Type II' & 12 & 0 & 94 & 2 & $108(17.3 \%)$ \\
Type IV & 15 & 3 & 1 & 78 & $97(15.5 \%)$ \\
\hline \multirow{2}{*}{ Total } & 272 & 102 & 166 & 86 & $626(100.0 \%)$ \\
& $(43.5 \%)$ & $(16.3 \%)$ & $(26.5 \%)$ & $(13.7 \%)$ & $(100.0 \%)$ \\
\hline
\end{tabular}

Table 5 Cross-tabulation of types I, II, III, and IV with types I', II', III', and IV' in the 741 patients

\begin{tabular}{crrrrr}
\hline & Type I & Type II & Type III & \multicolumn{1}{c}{ Type IV } & \multicolumn{1}{c}{ Total } \\
\hline Type I & 272 & 20 & 96 & 11 & $399(53.8 \%)$ \\
Type II & 2 & 93 & 0 & 0 & $95(12.8 \%)$ \\
Type III & 32 & 0 & 93 & 3 & $128(17.3 \%)$ \\
Type IV & 8 & 3 & 6 & 102 & $119(16.1 \%)$ \\
\hline \multirow{2}{*}{ Total } & 314 & 116 & 195 & 116 & $741(100.0 \%)$ \\
& $\left(42.4^{\circ}{ }_{0}\right)$ & $(15.7 \%)$ & $(26.3 \%)$ & $(15.7 \%)$ & $(100.0 \%)$ \\
\hline
\end{tabular}

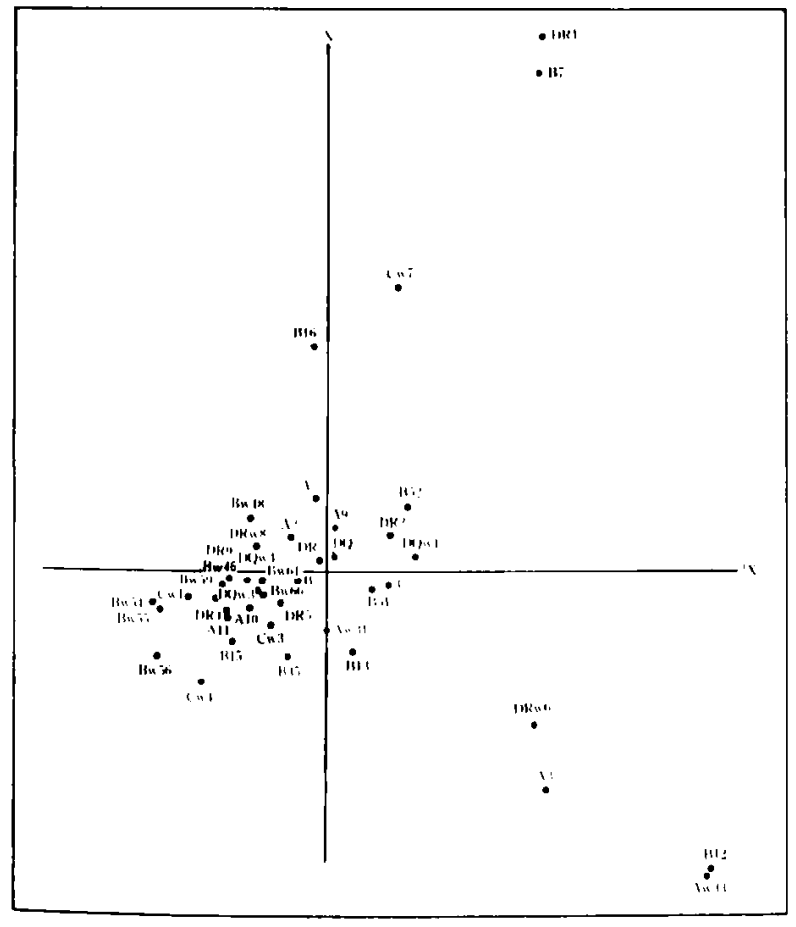

Fig. 3 Scaltergram of the HLA antigens in 741 patients clusters of HLA antigens (Fig. 2). We divided the 626 patients into four types ( I - IV) according to the functions shown in Table 2. Type II patients are characterized by HLA antigens of cluster b, type III by cluster $c$ and type $\mathrm{V}$ by cluster $\mathrm{d}$. Type $\mathrm{I}$ is a common type that does not show any characteristics.

We then defined three other groups. $T(b)$ was a group of responders who had 2 or more HLA antigens of cluster $b$, while the rest of the patients were $N(b) . T(c)$ was a group of responders who had 3 or more HLA antigens of cluster $c$, and while the rest were $N(c)$. T(d) was a group of responders who had 2 or more HLA antigens of cluster $d$, while the rest were $N(d)$. The relationship between cluster types and groups obtained by counting the number of HLA antigens is shown in Table 3. A detailed classification of the patients was performed as follows: ( $T$ (b) \& $N($ c) \& $N(d)$ ) or ( $T(b) \&$ $\mathrm{T}$ (c) \& $\mathrm{N}(\mathrm{d})$ ) was classed as type II', (N(b) \& $\mathrm{T}(\mathrm{c})$ \& $N(d))$ or ( $N(b) \& T(c) \& T(d))$ was classed as type III', (N(b) \& $N(c) \& T(d))$ or ( $T(b) \& N(c) \& T(d))$ was classed as type $\mathrm{N}^{\prime}$, and all others were called type I'. Table 4 shows the relationships between types I to IV 
and types I' to IV'.

A scatergram of the HLA antigen status of 741 patients is shown in Figure 3, with the results being almost the same as in the previous patients. The relationship between patient types classified by HLA cluster and by the number of HLA antigens is shown in Table 5.

\section{Discussion}

We used a method of quantification of response pattern and classified similar HLA antigens into four groups. This method is usually used for multidimensional data analysis, e. g. , in the survey of national character ${ }^{8.9)}$, and is one method of classifying individuals based on the similarity of their pattern of categorical responses to questions. Using this method, the correspondence of two configurations of the individuals and the categories in multidimensional Euclidian space can be used to make inferences with regard to their categories.

We previously reported on the distribution of HLA antigens in gastric cancer patients ${ }^{1)}$. The results of the previous and present studies were very similar. However, slight axis rotaion and a slightly different location was noted in this study, especially for clusters a and c. Despite this, the structure remained stable and the HLA antigens in each cluster were almost stable. So there was no major difference between these studies. Thus, the classification of HLA antigens by quantification analysis is stable, but patients cannot be classified by a fixed equation. Therefore, a simple new classification based on the number of HLA antigens was developed to apply clinically. A prospective randomized study using this new classification is now on going to confirm its clinical value in gastric cancer patients.

\section{References}

1) Ogoshi K, Mitomi T, Tsuji K, Hayashi C. HLA antigen status and outcome of postoperative adjuvant immunochemotherapy in gastric cancer: A multidimensional data analysis. Ann Cancer Res Ther, 2 : 95-99, 1993.

2) Akoh JA, Macintyre IMC. Improving survival in gastric cancer : review of 5-year survival rates in English language publications from 1970. Br J Surg, $79: 293-299,1992$.

3) Fielding JWI. Gastric cancer : different diseases. Br J Surg, 76 : $1227,1989$.

4) Hayashi C. Theory and example of quantification (II). Proc Inst Statist Math, $4: 19-30,1956$

5) Hayashi C. Quantification method III or correspondence analysis in medical science. Ann Cancer Res Ther, $1: 17-21$, 1992.

6) Benzécri JP. L'Analyse des Données, Tome $1:$ La Taxinomie, Tome 2 : L'Analyse des Correspondances. 4th edition, Paris : Dunod, 1984

7) Lebart L, Morineau A, Warwick KM, translated by Berry EM: Multivariate descriptive statistical analysis : Correspondence analysis and related techniques for large matrices. New York: Wiley, 1984. Originally published as Technique de la description statistique: Methodes et Logiciels pour l'Analyse des Grands Tableaux, Paris : Dunod, 1977.

8) Hayashi C. Statistical study on Japanese national character. J Japan Statist Soc (Special Issue) : 71-95, 1987.

9) Hayashi C. Belief systems and the Japanese way of thinking: interchronological and international perspectives. In: Motoaki H. Misumi J, Wilpert B, eds. Proceedings of the 22nd International Congress of Applied Psychology. Hove, UK: Lawrence Erlbaum Associates Ltd. , 3: 3-34, 1992. 
Correlation between argyrophilic nucleolar organizer regions and immunostaining for carbohydrate. antigen $19-9$ in human gastric cancers

P113 116

Haruhiko Nagami et al.

[目的］胃癌における腫瘍組織内CA19-9の免疫組 織化学的発現を検討寸ると同時に, 腫锡生物学的悪性度 の一指標であるAgNORs数を測定し，CA19-9染色強度 とAgNORs数との相関を検討した。 また, 臨床病理学的 因子別にAgNORs数, CA19-9発現率を求如比較検討した.

[对象と方法］胃癌50症例を对象に，ホルマリン固定 後のパラフィン切片を用い癌部の薄切片を作製後, Plotonらの方法に準じ銀染色を行い, 腫瑒細胞核200個の 総AgNORs数を求め，1核当たりのAgNORs数を求めた。 同時に抗CA19-9モノクローナル抗体を用い，SAB法に より腫瘍組織内を免疫組織化学的染色した。なお, 染 色強度は $\mathrm{G}_{0}$ : negative type, $\mathrm{G}_{1}$ : apical or focal cytoplasmic type, $G_{2}$ : diffuse cytoplasmic type, $G_{3}$ : stromal typeの 4 型に分類した。

[結＼cjkstart果］（1）胃癌50例中, 早期胃癌, 進行胃癌の

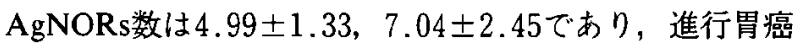
が有意に高值であった。また，CA19-9の発現は33例 (66.0\%)において認められた。

(2) 染色強度別の AgNORs 数は $G_{0}: 5.19 \pm 1.63$ $(\mathrm{n}=17), \mathrm{G}_{1}: 5.78 \pm 2.26(\mathrm{n}=5), \mathrm{G}_{2}: 6.82 \pm 2.23$ $(\mathrm{n}=16), \mathrm{G}_{3}: 7.76 \pm 2.80(\mathrm{n}=12)$ であり, $\mathrm{G}_{2}, \mathrm{G}_{3}$ は $\mathrm{G}_{0}$ にくらべ有意に高值であった。

(3) 病理学的因子别にみたAgNORs数は肉眼的進行度 別にはstage IVは stage I， IIにくらべ有意に高值であ $\eta$ ，腹膜播種性転移陽性例，漿膜浸潤陽性例，リンパ節 転移陽性例においてAgNORs数は有意に高值であった。

(4) 病理学的因子とCA19-9染色陽性率との関連は有 意な相関は認めなかった。

(5) 胃癌50例の AgNORs数の平均值である6.48をcut off pointとして50症例をAgNORs高值群，低值群に 2 分 し, 累積生存率を求めたところ, AgNORs高值群の予後 が有意に有効であった。

[考 察] 胃癌における腫瘍組織内CA19-9発現は古 くはAtokinsonらの報告があるものの，いまだその臨床 病理学的意義については明らかではない，今回，筆者ら の症例では33例 $(66.0 \%)$ にその発現を認めたか，病理 学的因子との相関は認めなかった。一方，腫湯增殖能を 反映するAgNORs数については進行癌は早期癌にくらべ 有意に高値であり，さきの癌組織内CA19-9発現形式別 にみれば, diffuse cytoplasmic type, stromal typeにおい てAgNORs数は高值であり, 腫場增殖能の強度な細胞は 機能的にCA19-9産生が元進している点がうかがえた。 胃癌において癌進展度の強度例はAgNORs数は高值であ クその相関性が認められた。ささらに, AgNORs数高値群 は明らかに予後不良であり，胃癌における予後規定因子 になりうる可能性が示唆された。
Classification of gastric cancer patients based on HLA antigen expression using quantification method III P117 120

Fumi Hayashi et al.

HLA抗原によって胃癌の治療に对する反応が予测で き, HLA抗原を測定することにより, 癌患者個人個人に 適切な治療ができることをすでに発表している．本研究 では，HLA抗原治療効果の関係をみるための，HLA抗原 に基づく胃癌患者の分類を，数量化III類を使って行った. さらに臨床の場で適用しやすいようにその簡便な分類法 を示した。

数量化III類は林の開発した多次元解析の一つであり, 調查对象 (患者)の調查項目 (HLA抗原)八の反応パター ンから項目の分類，対象の分類を同時に行うという考之 方に基づく方法である。まず，626人のデータから分析 し，後に741人のデータについて分析し，その安定性を確 認した。

HLA抗原は $1 \%$ 以上の頻度のあるものを取り上げ，次 の42抗原についての分析となった。

数量化分析の結果得られた 42 抗原の付置から，四つの クラスターができることがわかった。 bクラスターは A3, A33, B12, B13, DR6 : cクラスターはBw46, Bw54, Bw55, Bw56, Bw59, Cw1, DR4, DQw4, Bw54, Bw55, Bw56 : dクラスターは, B7, B15, Cw7, DR1 で，残りが aクラスターである。これに対応して得られる患者の付 置加患者を四つの型（I 型，II型，III型，IV型）に分 けることができる。この患者の型はもっているHLA抗原 をパターンでみた特徴としてとらえた分類である。

ここで，この特徎を簡便にとらえるために，別の分類 を考之た， $\mathrm{T}(\mathrm{b})$ はクラスター $\mathrm{b}$ のHLA抗原を二つ以上 もつ患者でそれ以外が $\mathrm{N}(\mathrm{b}) ， \mathrm{~T}(\mathrm{c})$ はクラスター $\mathrm{c}$ の HLA抗原を三つ以上もつ患者でそれ以外が $\mathrm{N}$ (c)， $\mathrm{T}$ (d) はクラスターdのHLA抗原を二つ以上もつ患者で それ以外が $\mathrm{N}(\mathrm{d})$ ，とした。これらの三つの分類は重複 しているので改めてつきのように四つの型を作成した。 すなわち, (T(b)\&N(c)\&N(d)) or (T(b)\&T(c)\&N(d))なら ば I’型, (N(b)\&T(c)\&N(d)) or (N(b)\& $T(c) \& T(d)) な$ らばII'型, (N(b)\& N (c) \& $\mathrm{T}(\mathrm{d}))$ or $(\mathrm{T}(\mathrm{b}) \& \mathrm{~N}(\mathrm{c})) \&$ T(d))ならば III'型，そしてこれ以外のすべてをIV'型と した. I 〜IVの型分類と I'〜IV'の型分類との相関は非常 に高いことが示された。

741例のデータに関しても同様の分析を行った結果, 42 抗原の付置に多少の違いはあるが，クラスターとして安 定していることが示された２ 2 種類の群分けの相関関係 も同様に安定していた。このことから，データが新しく なるごとに数量化III類の分析を行わなくても，決まった クラスターに属するHLA抗原の数を数えていけば作成 できる後述のI'〜IV'の群分けは, 今後臨床データで治療 効果とHLA抗原の関係をみていくうえで有用である. 